Volume 8. No. 10, October 2020

International Journal of Emerging Trends in Engineering Research

Available Online at http://www.warse.org/IJETER/static/pdf/file/ijeter418102020.pdf https://doi.org/10.30534/ijeter/2020/418102020

\title{
Self-Compacting Concrete with no Flyash and with Low Level of Flyash - A Comparative Study
}

\author{
Dr. V. Subramania Bharathi ${ }^{1}$, Dr. K. Mohammed Imthathullahkhan ${ }^{2}$ \\ ${ }^{1}$ Professor and Head, Department of Civil Engineering, Lords Institute of Engineering and \\ Technology, Hyderabad. vsbcivil@gmail.com \\ ${ }^{2}$ Associate Professor, Department of Civil Engineering, Lords Institute of Engineering and \\ Technology, Hyderabad
}

\begin{abstract}
Self- Compacting Concrete (SCC) was developed to make quality concrete [1] This project focuses on the rheological characteristics of SCC and also the mechanical properties. The mix proportions have been arrived and in this study the quantities of cement are varied and the water- powder ratio is kept as 0.4 throughout the study. Chemical admixtures are used in this study in order to achieve the workability characteristics.
\end{abstract}

Key words : Self-compacting concrete, Super Plasticizer, Flyash, Workability.

\section{INTRODUCTION}

To achieve a high flow rate and to avoid obstruction by closely spaced reinforcement, SCC is designed with limits on the nominal maximum size of the aggregate, the amount of aggregate and aggregate grading. [3]

SCC which flows under its own weight and fills into every corner of form work and passes through even restricted spacing of reinforcement, without the need for vibration. The transition zone in SCC is free of micro cracks, in contrast to the normal concrete.[4] In order to get a homogeneous and stable mix in SCC a large amount of powder element plus pozzolanic additions is required so that neither water nor slurry separates out [5-7].

\section{EXPERIMENTAL PROGRAM}

The investigation was conducted related to the variations in the dosage of chemical admixtures, the funnel speed and the height of rise in the box test [9]. The changes in workability characteristics caused due to this variation of plasticizer dosage were also investigated and given in the Table 3.

In the first investigation the powder content has been kept as $500 \mathrm{~kg} / \mathrm{m}^{3}$ and 21 mixes (CF1- CF21) have been tested in order to achieve the SCC characteristics. Then, the powder content is reduced to $400 \mathrm{~kg} / \mathrm{m}^{3}$ and again its fresh state characteristics are studied by various mixes $(\mathrm{S} 1-\mathrm{S} 7)$. Table 2. gives the details of the mix compositions with different chemical admixture dosage taken for the investigation [12].

Table 1. Typical Range of SCC mix composition

\begin{tabular}{|c|c|c|c|}
\hline Constituent & $\begin{array}{c}\text { Typical range } \\
\text { by mass } \\
\left(\mathbf{k g} / \mathbf{m}^{\mathbf{3}}\right)\end{array}$ & $\begin{array}{c}\text { Investigation } \\
\mathbf{1}\end{array}$ & $\begin{array}{c}\text { Investigation } \\
\mathbf{2}\end{array}$ \\
\hline Powder & $380-600$ & 500 & 400 \\
\hline Water & $150-210$ & 200 & 200 \\
\hline $\begin{array}{c}\text { Coarse } \\
\text { aggregate }\end{array}$ & $750-1000$ & 900 & 900 \\
\hline $\begin{array}{c}\text { Fine } \\
\text { aggregate }\end{array}$ & $\begin{array}{c}48-55 \% \text { of } \\
\text { total aggregate } \\
\text { weight }\end{array}$ & $50 \%$ & $50 \%$ \\
\hline
\end{tabular}

Table 2. Mix composition taken for the investigation

\begin{tabular}{|c|c|c|c|c|c|c|c|c|}
\hline $\begin{array}{c}\text { Mix } \\
\text { no. }\end{array}$ & $\begin{array}{c}\text { Cement } \\
(\mathbf{k g})\end{array}$ & $\begin{array}{c}\text { Fly } \\
\mathbf{a s h} \\
(\boldsymbol{\%})\end{array}$ & $\begin{array}{c}\text { Fly } \\
\text { Ash } \\
(\mathbf{k g})\end{array}$ & $\begin{array}{c}\text { Sand } \\
(\mathbf{k g})\end{array}$ & $\begin{array}{c}\text { Coarse } \\
\text { Aggregate } \\
(\mathbf{k g})\end{array}$ & $\begin{array}{c}\text { Water } \\
(\mathbf{k g})\end{array}$ & $\begin{array}{c}\text { Glenium } \\
\mathbf{B 2 3 3} \\
(\mathbf{\%})\end{array}$ & $\begin{array}{c}\text { Glenium } \\
\text { Stream2 } \\
(\%)\end{array}$ \\
\hline CF1 & 12.5 & 0 & 0 & 22.5 & 22.5 & 5 & 0 & 0 \\
\hline CF2 & 9.375 & 25 & 3.125 & 22.5 & 22.5 & 5 & 0 & 0 \\
\hline CF5 & 12.5 & 0 & 0 & 22.5 & 22.5 & 5 & 0.50 & 0 \\
\hline CF6 & 9.375 & 25 & 3.125 & 22.5 & 22.5 & 5 & 0.50 & 0 \\
\hline CF9 & 12.5 & 0 & 0 & 22.5 & 22.5 & 5 & 0.75 & 0 \\
\hline CF10 & 9.375 & 25 & 3.125 & 22.5 & 22.5 & 5 & 0.75 & 0 \\
\hline CF11 & 12.5 & 0 & 0 & 22.5 & 22.5 & 5 & 1 & 0 \\
\hline CF12 & 9.375 & 25 & 3.125 & 22.5 & 22.5 & 5 & 1 & 0 \\
\hline CF13 & 12.5 & 0 & 0 & 22.5 & 22.5 & 5 & 0 & 0.10 \\
\hline CF14 & 12.5 & 0 & 0 & 22.5 & 22.5 & 5 & 2 & 0 \\
\hline CF15 & 13.75 & 0 & 0 & 24.75 & 24.75 & 5.5 & 2 & 0 \\
\hline CF16 & 13.75 & 0 & 0 & 24.75 & 24.75 & 5.5 & 2.50 & 0.15 \\
\hline CF17 & 13.75 & 0 & 0 & 24.75 & 24.75 & 5.5 & 2.50 & 0.30 \\
\hline CF18 & 13.75 & 0 & 0 & 24.75 & 24.75 & 5.5 & 5 & 0.30 \\
\hline CF19 & 10.3125 & 25 & 3.4375 & 24.75 & 24.75 & 5.5 & 5 & 0.30 \\
\hline S1 & 11 & 0 & 0 & 24.75 & 24.75 & 5.5 & 4.5 & 0.3 \\
\hline S2 & 11 & 0 & 0 & 24.75 & 24.75 & 5.5 & 5 & 0.3 \\
\hline S3 & 11 & 0 & 0 & 24.75 & 24.75 & 5.5 & 5.5 & 0.4 \\
\hline S4 & 8.25 & 25 & 2.75 & 24.75 & 24.75 & 5.5 & 5.5 & 0.4 \\
\hline S7 & 11 & 0 & 0 & 24.75 & 24.75 & 5.5 & 6 & 0 \\
\hline
\end{tabular}




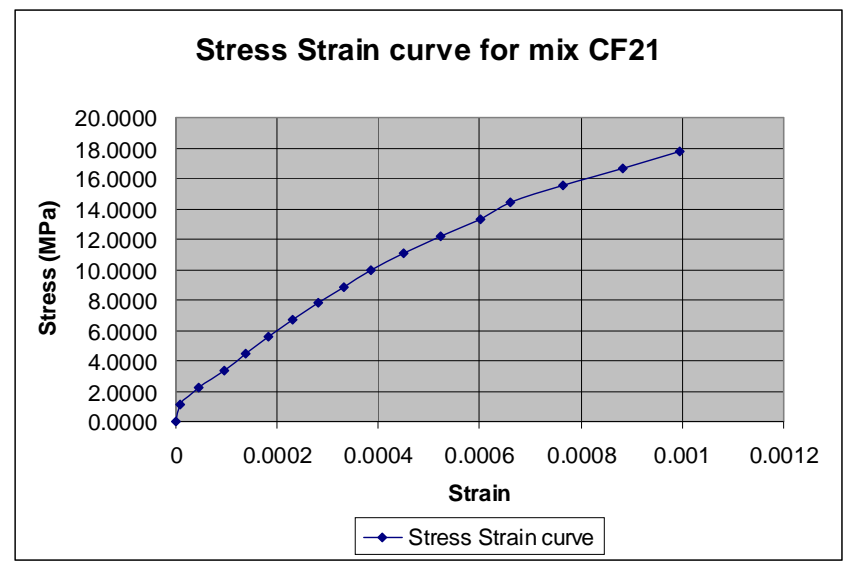

Figure 1. Typical stess strain curve

Comparison of Slump Spread

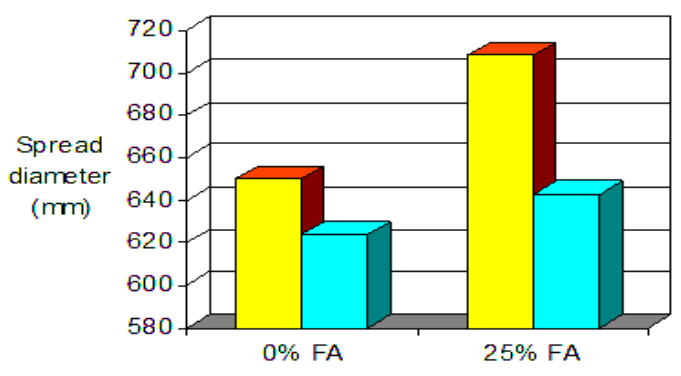

Fly ash content (\%)

$\square$ Pow der(500 kg/cu.m), $5 \%$ WRA , $0.3 \%$ VWA, (CF18-CF21) 口 Pow der(400 kg/cu.m), 5.5\% WRA, 0.4\% VWA,(S3-S6)

Figure 2. Comparison of slump spread

The SCC mix proportions that were obtained using EFNARC [2] are capable of achieving the SCC characteristics with the replacement of cement by fly ash. More than 25 mixes were carried out to examine the SCC characteristics for developing High Volume Fly ash Self Compacting Concrete (HVFSCC) mixes for Indian conditions [11]. These mixes were proportioned with total powder (cement plus fly ash) contents of $500 \mathrm{~kg} / \mathrm{m} 3$ and $400 \mathrm{~kg} / \mathrm{m}^{3}$.

Cement replacement level ranging from 0 to $25 \%$ of fly ash and the water/powder ratio as 0.4 for $500 \mathrm{~kg} / \mathrm{m}^{3}$ and 0.5 for $400 \mathrm{~kg} / \mathrm{m}^{3}$ were considered in the study. Coarse and fine aggregate contents are kept as $900 \mathrm{~kg} / \mathrm{m}^{3}$ throughout the investigation and the chemical admixture dosage is varied in order to obtain the SCC characteristics [8-9].

The optimum dosage of the Glenium B233 is found to be 5\% for mixes CF18 to CF21 and 5.5\% for mixes S3 to S6 when combined with Glenium stream 2 of $0.3 \%$ for mixes CF18-CF21 and $0.4 \%$ for mixes S3-S6. The test results of the workability investigations are summarized in Table 3. Based on the test results, various classes of SCC as per EFNARC [2] are shown in Table 4. It is observed that mix CF19 satisfies all the classes of SCC. Also, the results clearly explain that the high volume

Table 3. Workability test results

\begin{tabular}{|c|c|c|c|c|c|c|}
\hline Mix no. & $\begin{array}{c}\text { Slump } \\
\text { Spread } \\
\text { (mm) }\end{array}$ & $\begin{array}{c}\text { T500 } \\
\text { (sec) }\end{array}$ & $\begin{array}{c}\text { J ring } \\
\text { height } \\
\text { (mm) }\end{array}$ & $\begin{array}{c}\text { Time for V } \\
\text { funnel } \\
\text { (sec) }\end{array}$ & $\begin{array}{c}\text { Filling } \\
\text { Height } \\
\text { U box } \\
\text { (mm) }\end{array}$ & $\begin{array}{c}\text { L box } \\
\text { h2/h1 }\end{array}$ \\
\hline CF1 & - & - & - & - & - & - \\
\hline CF2 & - & - & - & - & - & - \\
\hline CF5 & 250 & - & - & - & - & - \\
\hline CF6 & 250 & - & - & - & - & - \\
\hline CF9 & 300 & - & - & - & - & - \\
\hline CF10 & 320 & - & - & - & - & - \\
\hline CF11 & 420 & - & - & - & - & - \\
\hline CF12 & 450 & - & - & - & - & - \\
\hline CF13 & - & - & - & - & - & - \\
\hline CF14 & 580 & 5.63 & 240 & - & - & - \\
\hline CF15 & 600 & 5.22 & 230 & - & - & - \\
\hline CF16 & 560 & 4.65 & 215 & 22.65 & 230 & 0.31 \\
\hline CF17 & 575 & 4.18 & 196 & 20.12 & 238 & 0.35 \\
\hline CF18 & 650 & 4.05 & 110 & 11 & 320 & 0.5 \\
\hline CF19 & 708 & 2.25 & 97 & 7 & 326 & 0.82 \\
\hline S1 & 575 & 5.8 & 185 & 24 & 285 & 0.5 \\
\hline S2 & 615 & 5.2 & 158 & 22.5 & 294 & 0.6 \\
\hline S3 & 624 & 4.8 & 135 & 18 & 302 & 0.66 \\
\hline S4 & 643 & 4.5 & 94 & 11 & 304 & 0.68 \\
\hline S7 & - & - & - & - & - & - \\
\hline & & & & & & \\
\hline
\end{tabular}

Table 4. Various classes for the SCC mixes

\begin{tabular}{|c|c|c|c|}
\hline Mix No. & Slump flow class & Viscosity class & $\begin{array}{c}\text { Passing } \\
\text { ability class }\end{array}$ \\
\hline CF14 & SF1 & & \\
\hline CF15 & SF1 & & \\
\hline CF16 & SF1 & VS2/VF2 & \\
\hline CF17 & SF1 & VS2/VF2 & \\
\hline CF18 & SF1 & VS2/VF2 & \\
\hline CF19 & SF2 & VS2/VF2 & PA2 \\
\hline S1 & SF1 & VS2/VF2 & \\
\hline S2 & SF1 & VS2/VF2 & \\
\hline S3 & SF1 & VS2/VF2 & \\
\hline S4 & SF1 & VS2/VF2 & \\
\hline
\end{tabular}

The hardened concrete results are summarized in Table 5. It is observed that the replacement of cement with fly ash as carried out has decreased the strength parameters at 28 days [10]. The average 28 days compressive strength is varied in the range of 15 to $30 \mathrm{MPa}$.

From the above discussion, it was found that it is difficult to achieve the self-compacting properties without the fly ash content and chemical admixtures. Table 6 gives the details of the Mix proportions for the required strength. 
Table 5. Hardened concrete test results

\begin{tabular}{|c|c|c|c|c|}
\hline $\begin{array}{c}\text { Mix. } \\
\text { No }\end{array}$ & $\begin{array}{c}\text { Compressive } \\
\text { strength } \\
\text { (MPa) }\end{array}$ & $\begin{array}{c}\text { Split } \\
\text { tensile } \\
\text { strength } \\
\text { (MPa) }\end{array}$ & $\begin{array}{c}\text { Flexural } \\
\text { strength } \\
\text { (MPa) }\end{array}$ & $\begin{array}{c}\text { Young's } \\
\text { modulus } \\
\text { (MPa) }\end{array}$ \\
\hline CF14 & 35.3 & 4.1 & 8.83 & 29169 \\
\hline CF15 & 36 & 4.5 & 8.3 & 32315 \\
\hline CF16 & 35.8 & 3.3 & 7.02 & 30249 \\
\hline CF17 & 36.6 & 3.9 & 6.8 & 31335 \\
\hline CF18 & 39.7 & 4.3 & 5.2 & 33439 \\
\hline CF19 & 27.9 & 3.5 & 5.16 & 26466 \\
\hline S1 & 36.5 & 3.8 & 4.1 & 31674 \\
\hline S2 & 37.2 & 3.5 & 3.8 & 35065 \\
\hline S3 & 38.4 & 3.7 & 4.2 & 32360 \\
\hline S4 & 26.5 & 3.4 & 4.6 & 26424 \\
\hline
\end{tabular}

Table 6. Mix proportions for required strength

\begin{tabular}{|c|c|c|c|c|c|c|}
\hline $\begin{array}{c}\text { Mix } \\
\text { Ratio }\end{array}$ & $\begin{array}{c}\text { W/P } \\
\text { rati } \\
\mathbf{o}\end{array}$ & $\begin{array}{c}\text { WRA } \\
(\boldsymbol{\%})\end{array}$ & $\begin{array}{c}\text { VMA } \\
(\boldsymbol{\%})\end{array}$ & $\begin{array}{c}\text { Replacemen } \\
\text { t of cement } \\
\text { by fly ash } \\
(\boldsymbol{\%})\end{array}$ & $\begin{array}{c}\text { Proposed } \\
\text { Compressiv } \\
\text { e Strength } \\
(\mathbf{M P a})\end{array}$ & $\begin{array}{c}\text { Obtained } \\
\text { compressiv } \\
\text { e strength } \\
\text { (MPa) }\end{array}$ \\
\hline $1: 1.8: 1.8$ & 0.4 & 5 & 0.3 & 25 & 30 & 27.9 \\
\hline $1: 1.8: 1.8$ & 0.4 & 5 & 0.3 & 50 & 25 & 25 \\
\hline $1: 1.8: 1.8$ & 0.4 & 5 & 0.3 & 75 & 20 & 20 \\
\hline $1: 2.25:$ & 0.5 & 5.5 & 0.4 & 50 & 20 & 21 \\
\hline 2.25 & & & & &
\end{tabular}

\section{CONCLUSION}

Following are the conclusions we could arrive from this project.

To achieve the self-compacting properties the mix should contain more fly ash, that is up to 25 replacement of cement by fly ash and the WRA should be used along with VMA.

Cement can be replaced by fly ash up to $25 \%$ in order to obtain the SCC characteristics with 28 days compressive strength of $20 \mathrm{MPa}$. It is also possible to obtain the SCC characteristics by reducing the powder content as low as $400 \mathrm{~kg} / \mathrm{m}^{3}$ with a little increase in VMA dosage ( $0.3 \%$ to $0.4 \% \mathrm{~S} 3$ to $\mathrm{S} 4$ mixes) or no increase in VMA dosage ( $0.3 \%$ only $\mathrm{S} 1$ to $\mathrm{S} 2$ mixes) The visual assessment of various mixes showed that VMA is necessary for achieving SCC characteristics without segregation for both the powder contents $400 \mathrm{~kg} / \mathrm{m} 2$ ( CF 16 to CF 19)as well as $500 \mathrm{~kg} / \mathrm{m} 3(\mathrm{~S} 1$ to $\mathrm{S} 6$ ).

Here we get remarkable results when SCC is made with a fly ash replacement of 25 percent and a fine aggregate half of the total aggregate. The water- powder ratio was 0.4 .

SCC mix requires high powder content $\left(500 \mathrm{~kg} / \mathrm{m}^{3}\right)$, lesser quantity of coarse aggregate $\left(900 \mathrm{~kg} / \mathrm{m}^{3}\right)$, high range $\mathrm{SP}$ ( 5 to $5.5 \%$ of cementitious material) and VMA $(0.3 \%$ to $0.4 \%$ of cementitious material) to give stability and fluidity to the concrete mix.
It is possible to achieve strengths varying from $15-30 \mathrm{MPa}$ when the cement is replaced by high volume of fly ash. The optimum dosage of the Glenium B233 is found to be 5\% for mixes CF18-CF21 and 5.5\% for mixes S3-S6 when combined with Glenium stream 2 of $0.3 \%$ for mixes CF18-CF21 and $0.4 \%$ for mixes S3-S6.

\section{REFERENCES}

1. H. Okamura, and M. Ouchi M, Self - Compacting Concrete, Journal of Advanced Concrete Technology Vol.1, , pp 5-15, 2003.

2. EFNARC, The European guidelines for Self-Compacting Concrete specification, Production and Use, May 2005.

3. A.R. Santhakumar, Concrete Technology, Oxford University Press, First Edition, pp. 687- 693, 2007.

4. Praveen kumar and S.K. Kaushik, Transition zone in self compacting concrete, Indian Concrete Journal, pp 60-65, June 2004.

5. V. Kumar, B.N Roy, and A.S.R. Sai, Effect of Super Plasticizer on concrete, Indian Concrete Journal, pp. 31-33, Jan 1989.

6. P.L. Domone, Self-compacting concrete: An analysis of 11 years of case studies, Cement \& concrete composites, Vol.28, pp. 197-208, 2006.

7. Burak Felegoglu, Selcuk Turkel, and Bulent Baradam, Effect of water/cement ratio on the fresh and hardened properties of self-compacting concrete, Building and Environment

8. G. De schutter, Guidelines for testing fresh self-compacting concrete, European research project, www.civeng.ucl.ac.u.k., Sep 2005.

9. S.Aravindan et al Characteristic Study of Concrete by Replacing Glass Cullet and Ceramic Tiles over Conventional Aggregates, INTERNATIONAL JOURNAL OF SCIENTIFIC \& TECHNOLOGY RESEARCH, VOLUME 8, ISSUE 10, OCTOBER 2019, Page no - $1802-1805$.

10. D.S.Vijayan, A. Leema Rose, P.Dinesh Kumar, V.Gokulnath, D Parthiban, "Sustainable Efficiency of Hypo Sludge in Concrete", International Journal of Emerging Trends in Engineering Research, Volume 8. No. 9, September 2020, https://doi.org/10.30534/ijeter/2020/94892020

11. D. S. Vijayan, et al., An experimental study on mechanical and durable properties of self-curing concrete by adding admixture, Materials Today: Proceedings, https://doi.org/10.1016/j.matpr.2020.05.071

12. D. Parthiban et al., Performance evaluation of Fly ash based GPC with partial replacement of RHA as a cementitious material, Materials Today: Proceedings, https://doi.org/10.1016/j.matpr.2020.05.244 